\title{
Analysis of Htra Gene from Zebrafish (Danio Rerio) Murwantoko $^{1 *}$, Chio Oka ${ }^{2}$ and Masashi Kawaichi ${ }^{2}$
}

1. Department of Fisheries, Faculty of Agriculture, Gadjah Mada University, Bulaksumur, Yogyakarta 55281, Indonesia.

2. Laboratory of Gene Function in Animals, Department of Molecular Biology, Graduate School of Biological Science, Nara Institute of Science and Technology 8916-5 Takayama, Ikoma, Nara 630-0101, Japan.

\begin{abstract}
HtrA which is characterized by the combination of a trypsin-like catalytic domain with at least one C-terminal PDZ domain is a highly conserved family of serine proteases found in a wide range of organisms. However the identified HtrA family numbers varies among spesies, for example the number of mammalian, Eschericia coli, fruit fly-HtrA family are 4, 3 and 1 gene respectively. One gene is predicted exist in zebrafish. Since no complete information available on zebrafish HtrA, in this paper zebrafish HtrA (zHtrA) gene was analyzed. The zHtrA is belonged to HtrA1 member and predicted encodes 478 amino acids with a signal peptide, a IGF binding domain, a Kazal-type inhibitor domain in the up stream of HtrA-bacterial homolog. At the amino acid sequence the zHtrA1 showed the $69 \%, 69 \%, 68 \%, 54 \%$ and $54 \%$ with the rat HtrA1, mouse HtrA1, human HtrA1, human HtrA3 and mouse HtrA4 respectively. The zHtrA1 is firstly expressed at $60 \mathrm{hpf}$ and mainly in the vertebral rudiments in the tail region.
\end{abstract}

\section{Introduction}

HtrA which is characterized by the combination of a trypsin-like catalytic domain with at least one C-terminal PDZ domain is a highly conserved family of serine proteases found in a wide range of species including microbes, plants, and animals (Pallen and Wren, 1997; Clausen et al., 2002). The over 180 members of this family indicates that all sequences have a length around 350-450 amino acid residues. The number of HtrA family members were varies among species. Four, three and two HtrA members were identified in human; Eschericia coli and Synechocys; Arabidopsis thaliana respectively. Only one HtrA identified in Saccharomyces cerevisae, Schizosaccharomyces pombe, Candida albiicans

Corresponding author: Murwantoko, Department of Fisheries, Faculty of Agriculture, Gadjah Mada University, Jl. Flora Bulaksumur, Yogyakarta 55281, Indonesia. Tel/Fax: 62-274-51218; E-mail: murwantoko@yahoo.com and Drosophila melanogaster. In zebrafish (Danio rerio) one HtrA was predicted (Clausen et al., 2002).

From mammalian at least 4 members of HtrA, from HtrA1 to HtrA4 have been identified. The HtrA2 has mitochondrial signal and a unique transmembrane at Nterminal of bacterial HtrA-like. The human htrA2 is expressed in placenta and pancreas of normal human tissues and highly expressed in promyelocytic leukemia HL-60, chronic myelogenus leukemia K-562, Burkitt lymphoma Raji and human colorectal carcinoma SW480 cell lines (Faccio et al., 2000) and Omi is upregulated in mammalian cells in response to stress induced by both heat shock and tunicamycin treatment (Gray et al., 2002).

Mammalian HtrA3 have characteristic structural motifs which are shared with HtrA1. In contrast to HtrA2, those HtrAs are secretory proteins having a signal sequence for secretion at the N-terminus. Those HtrAs also contain insulin-like growth 
factor binding domain (IGFB), a Kazal type serine protease inhibitor domain at $\mathrm{N}$ terminal regions of bacterial-HtrA homology region. The expression of HtrA3 or pregnancy-related serine protease (PRSP) gene was low before pregnancy, but it was increased at implantation and markedly upregulated post-implantation. In-situ hybridization localized low levels of mRNA expression to the epithelium and stroma during very early pregnancy, but high expression to the decidual cells on day 8.5, primarily at the mesometrial pole where the placenta was forming (Nie et al., 2003). The HtrA1 (L56 or PRSS11) was originally isolated in differential screening for mRNAs repressed by SV40 transformation of human fibroblasts (Zumbrun and Trueb, 1996). HtrA1 was also independently isolated as a gene up-regulated in cartilage of human osteoathritic patients (Hu et al., 1998) and in aged joint cartilage (Ly et al., 2002). The HtrA1 mRNA was also known to be downregulated in ovarian cancer (Shridhar et al., 2002), malignant melanoma, (Baldi et al., 2002), primary brain tumors, and several cancer cell lines (Chien et al., 2004). This tumor suppressive activity of HtrA1 was largely dependent on the protease activity (Hu et al., 1998). Interaction of HtrA1 PDZ domain with partner protein regulates the proteolytic activity (Murwantoko et al., 2004).

HtrA is found in varies of a wide range of species. Four and three member of HtrA have been reported in human or mammalian and $E$. coli respectively, but only one member has been identified in fruit fly and one member was predicted in zebrafish (Clausen et al., 2002). In this paper we identified the zebrafish HtrA member and determined the expression.

\section{Materials and Methods \\ Primer and amplification}

The searching of amino acid homology of mouse HtrA1 to zebrafish data base indicated that two short fragment of cDNA shown high homology. The fj28a11 showed $65 \%$ identities to IGFB and KI domain. The fk91g02 showed $81 \%$ identities with serine protease and PDZ domains.

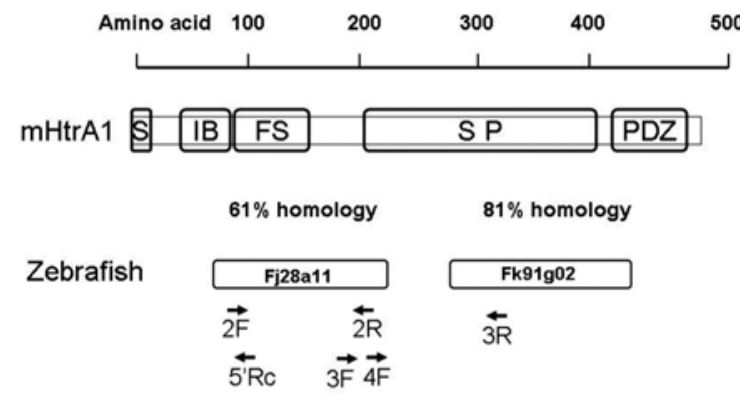

Figure 1. The homology between two fragments of zebrafish cDNA with mouse HtrA1 was presented. The relative position of Zeb-S8-2F (2F), Zeb-S8-2R (2R), Zeb-S8-3F (3F), Zeb-S8-4F (4F), Zeb-S8-3R (3R) and a set of $5^{\prime}$ Race $\left(5^{\prime} R c\right)$ primers were shown. $S=$ signal peptide, IB=IGF binding protein, $\mathrm{KI}=$ Kazal-type protease inhibitor, $\mathrm{PDZ}=\mathrm{PDZ}$ domain

The primers were design to amplify zebrafish Fj fragment, region between $\mathrm{Fk}$ and Fk fragments, $5^{\prime}$ terminal end. The pair primer Zeb-HtrA-2F (ATGGATTCGAGTG TGGAGAA GGTCTGGAA) and Zeb-HtrA2R (CTCTTAAGGGC TACCACATGA GCATTAG) were used amplify IGFBP-KI domains homolog. To amplify region between $\mathrm{Fk}$ and $\mathrm{Fj}$ region the sense primers ZEB-S8-3F (TATCGAATTCCTCATGT GGTAGCCAACA) and ZEB-S8-4F (GTG GGAATTCGCTCTGGTTTTGTGGTGTCT) were designed from the 3 '-end of fj fragment and one anti sense primer ZEB-S8-3R (TCTACT ATAGGTCTGATGGAATGGC GA AAG) was designed from $5^{\prime}$-end of $\mathrm{fk}$ fragment.

To identify the $5^{\prime}$ part of expected Zebrafish HtrA gene, the rapid amplification of 5' cDNA Ends (5' RACE) was done using Takara 5'-RACE Core Set (Takara Biomedicals). The $5^{\prime}$ phosporylated RT primers (CTGAAGCTTCTG) was used to 
synthesis first strand cDNA at $50^{\circ} \mathrm{C}$ for $1 \mathrm{~h}$. Degradation of hybrid RNA by RNAseH was done at $30^{\circ} \mathrm{C}$ for $1 \mathrm{~h}$ followed by circularization/ concontamerization at $16^{\circ} \mathrm{C}$ for overnight. The two primer pairs (Sense 1 GTGTGCGTGTGCAAGAGTTC Antisense 1 CGGTAGTCGTTGCACCAAC C; Sense 2 GTGTCCTACAGGAACATCTG Antisense 2 CATTCCAGACCTTCTCCAC TC) were used to amplify the longer and nested unidentified sequences respectively. The nested DNA fragment was sequenced. The determination of the $3^{\prime}$ end zHtrA was done by analysis on genomic sequences.

\section{RNA isolation and cDNA synthesis}

RNA was isolated from different stages of zebrafish using ISOGEN (Wako Pure Chemical Industries, Osaka, Japan) following manufacturer's instructions. In brief, the embryos were homogenized in Isogen followed by incubation at room temperature for $5 \mathrm{~min}$. The solutions were extracted with chloroform and incubated at RT for $3 \mathrm{~min}$. The supernatant fraction were precipitated with isopropanol and washed with $70 \%$ ethanol. Precipitated RNA was dissolved in DEPC-treated TE. One $\mu \mathrm{g}$ of total RNA was used to synthesize first strand cDNA using random primers at $37^{\circ} \mathrm{C}$ for $60 \mathrm{~min}$ (Pharmacia cDNA synthesis kit).

\section{HtrA expression by RT-PCR}

To identify the stage of fish expressing the HtrA, the $30 \mathrm{hpf}, 60 \mathrm{hpf}$ and adult stages of zebrafish cDNA were used for PCR. The pair primer Zeb-HtrA-2F and Zeb-HtrA-2R which predicted to amplify IGFBP-KI domains homolog were used. The amplification was performed $95^{\circ} \mathrm{C}(30 \mathrm{~s})$, $55^{\circ} \mathrm{C}(30 \mathrm{~s}), 72^{\circ} \mathrm{C}(1 \mathrm{~min})$ for 30 cycles. This fragment also cloned into pBSKSII (Stratagene).

\section{Whole mount in situ hybridization}

Recombinant plasmid of PBSKSII containing DNA fragment amplified using zeb-HtrA-2F / zeb-HtrA-2R primers was used in this experiment. Sense and antisense digoxigenin-labeled RNA probes were synthesized with a kit (Roche Diagnostics Heideberg, Germany) using T3 and T7 RNA polymerases (Boehringer Mannheim).

The various stages of zebrafish were fixed in $4 \%$ paraformaldehyde in PBS at $4^{\circ} \mathrm{C}$ for overnight. After removing the vitelline membrane, the fixed embryos were dehydrated in methanol and stored at $-20^{\circ} \mathrm{C}$. The embryos were rehydrated in PBS and the 70 hpf embryos were treated with $50 \mu \mathrm{g} /$ $\mathrm{ml}$ proteinase $\mathrm{K}$ for $5 \mathrm{~min}$. The embryos were further fixed in $4 \%$ paraformaldehyde in PBS for $20 \mathrm{~min}$. After two washes with PBST for $5 \mathrm{~min}$ each, the embryos were incubated in a prehybridization solution (50\% formamide, 5xSSC and 0,1\% Tween, $500 \mu \mathrm{g} / \mathrm{ml}$ yeast $\mathrm{tRNA}, 50 \mu \mathrm{g} / \mathrm{ml}$ heparin) at $56^{\circ} \mathrm{C}$ for $1 \mathrm{~h}$. Hybridization was carried out at $56^{\circ} \mathrm{C}$ overnight in the prehybridization solution supplemented with $3 \mu \mathrm{g} / \mathrm{ml}$ digoxigenine-labelled probe. After hybridization, excess probes were removed by washing in 2xSSC/ $50 \%$ formamide at $56^{\circ} \mathrm{C}$ for $1 \mathrm{~h}$ and by washing in 2XSSC at RT for 10 min twice. The embryos were washed in RNAse buffer (0.5 M NaCl, 10mM Tris-Hcl ( $\mathrm{pH} \mathrm{8.0)}$ contain $0.1 \%$ Twen 20 then treated with 20 $\mathrm{mg} / \mathrm{ml}$ RNase in RNase buffer at RT for 10 min. The embryos were washed with $2 \times S S C$ at RT and with 2 XSSC/50\% formamide, 2XSSC and $0.2 \times S S C$ at $55^{\circ} \mathrm{C}$ for $1 \mathrm{~h}, 15 \mathrm{~min}$ and 15 min respectively. Finally the embryos were washed with PBST at RT for $5 \mathrm{~min}$. The embryos were then treated with $1 \%$ blocking reagent (Boheringer Mannheim), containing $0.2 \%$ Tween 20 for $1 \mathrm{~h}$ and incubated overnight at $4^{\circ} \mathrm{C}$ with $1: 4000$ diluted of alkaline phosphatase-conjugated antidigoxigenin antibody in the blocking reagent. After extensive washing, the color 
was developed using NBT/BCIP. The embryos were fix in $4 \%$ PFA, $0.25 \%$ glutaraldehyde in PBS and destaining using acetone.

\section{Genomic analysis}

Genomic analysis using Genetyx program was used to predict amino acid sequences encoded by zebrafish HtrA. Comparison the sequences with the data in gene bank was done usin BLAST in NCBI. Prediction protein structure was done in NCBI protein structure. The comparison of the predicted amino acid sequences of zebrafish HtrA which other member was done using Clustal W (Thompson et al., 1994)

\section{Result \\ Identification of zebrafish HtrA}

The amplifiation using zeb-HtrA-2F/ zeb-HtrA-2R primers using adult cDNA as template gave result a fragment $430 \mathrm{bp}$ in size. This size was as been predicted since the primer will amplify from nucleotide 370 to 800 . This result showed that the cDNA contains $\mathrm{Fj}$ fragment. To verify the present of Fk fragments and whether those $\mathrm{Fj}$ and $\mathrm{Fk}$ fragments came from one gene, the two sense primers ZEB-S8-3F, ZEB-S8-4F which designed from the 3 '-end of fj fragment and one anti sense primer ZEB-S8-3R which designed from 5 '-end of fk fragment were used to amplify the cDNA in separate tube. The amplification produced single fragment on every primer pair. The DNA fragment which is produced by ZEB-S8-3F/ ZEB-S83R primer was larger than fragment of ZEBS8-4F/ ZEB-S8-3R primer, and at the fragments size were as been expected. Those results indicated that the Fk fragment was present in CDNA, and the $\mathrm{Fj}$ and $\mathrm{Fk}$ fragments were came from one gene. Next we identified entirely HtrA gene by RT PCR for the middle part, and by $5^{\prime}$-RACE for $5^{\prime}$ terminal ends. The comparison between Fk fragment and zebrafish genomic data bank resulted the 72 nucleotide in $3^{\prime}$ terminal ends. The sequence of entirely zebrafish HtrA gene and predicted amino acid sequences were presented in Figure 2.

Zebrafish HtrA sequences contained a clear 1330 nucleotidet (nt) ORF, with the start codon ATG at nt $139 \pm 141$ and stop codon TGA at nt 1467+1469; outside the ORF is a $5^{\prime}$ UTR $138 \mathrm{nt}$. The identical N-terminal ends of protein contain a predicted signal peptide (aa $1 \pm 22$ ). A search of the NCBI protein structure database showed that the longform protein contains aa sequences consistent with four other domains (Figure 1) : (i) an insulin-like growth factor (IGF)binding domain (aa 27士91), (ii) a Kazal-type Serine protease-inhibitor domain (aa $109 \pm 151$ ), (iii) a trypsin protease domain (aa $167 \pm 360$ ) and (iv) a PDZ domain (aa $379 \pm 476)$.

A comparison of the sequence (Figure 1) with entries in the GenBank databases (April 2004) showed the greatest homology were the mammalian HtrA1 proteins. At the amino acid sequence, the zHtrA1 has $69 \%$ identity of the sequence with the rat and mouse HtrA1 (accession numbers NP_113909, AAD52683, AD52682 and AAH13516), 68\% identity with human HtrA1 (NP_002766), 54\% with human HtrA3 (NP_444272) and 54\% with mouse HtrA4 (XP_284398). The homology alignment of those sequences is presented in Figure 3. 


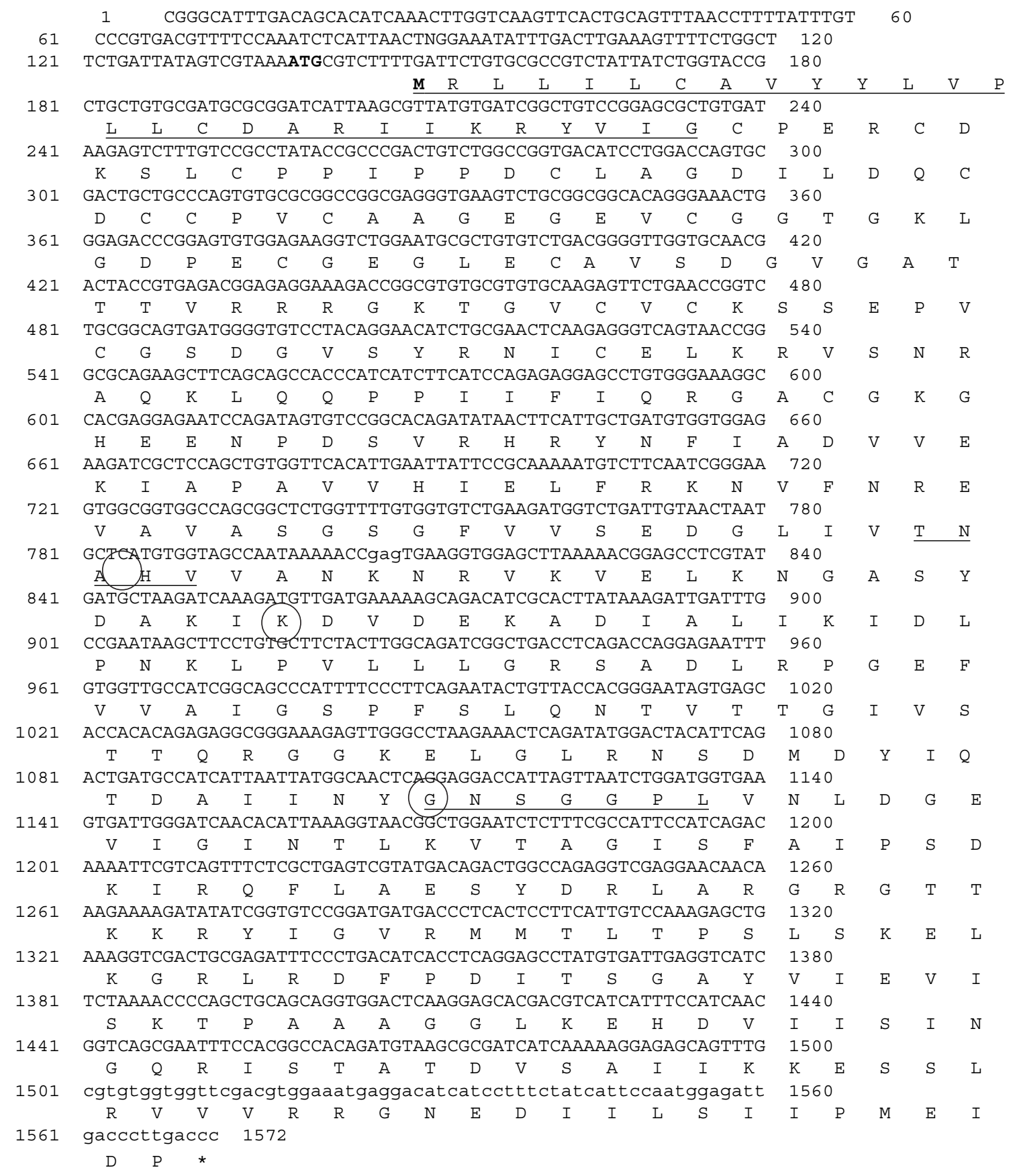

Figure 2. The mRNA zebrafish HtrA sequences and their deduced amino acid sequences. The start codon (ATG) are in bold. The active serine protease GNSGGPL and the additional TNAHV histidine residues are under lined and in bold. The catalytic triad amino acid His, Asp and Ser are circled. The lower case sequences was predicted from genomic sequence 
zeb-HtrA mus-HtrA1 hum-HtrA3 mus-HtrA4

zeb-HtrA mus-HtrA 1 hum-HtrA3 mus-HtrA4

zeb-HtrA mus-HtrA1 hum-HtrA 3 mus-HtrA4

zeb-HtrA mus-HtrA1 hum-HtrA 3 mus-HtrA4

zeb-HtrA mus-HtrA1 hum-HtrA3 mus-HtrA4

zeb-HtrA mus-HtrA1 hum-HtrA3 mus-HtrA4

zeb-HtrA mus-HtrA1 hum-HtrA 3 mus-HtrA4

zeb-HtrA mus-HtrA 1 hum-HtrA 3 mus-HtrA4

zeb-HtrA mus-HtrA1 hum-HtrA 3 mus-HtrA4
-MRLLILCAVYYLVPLLCDARI IKRYVIG_-CPERCDKSLCPPI PPDCLAGD-MQSLRTTLLSLLLLLLAAPSLALPSGTGRSAPAATVCPEHCDPTRCAPPPTDCEGGR-MQARALLLAALAALALAREPPAAP—CPARCDVSRCP-SPRCPGGY MSFQRLWAVRTQFLLLWLLLPAVPVPWAEARRSRVSLPCPDACDPTRCP - TLPTCSAGLA $: \quad * \quad * * * *: * . . *$ * $*$

- ILDQCDCCPVCAAGEGEVCGGTGKLGDPECGEGLECAVSDGVGATTTVRRRGKTGVCVC - VRDACGCCEVCGALEGAACG-LQEGPCGEGLQCVVPFGVPASATVRRRAQAGLCVC - VPDLCNCCLVCAASEGEPCGG-PLDSPCGESLECVR——GLCRC PVPDRCGCCRVCAAAEGQECGG-ARGRPCAPRLRCGAPFSRDPSGG-AWLGTCGC

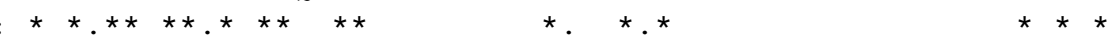

KS-SEPVCGSDGVSYRNI CELKRVSNRAQKLQQPP I IF IQRGACGKGHEENPDSVRHR AS-SEPVCGSDAKTYTNLCQLRAASRRSEKLRQP PVIVLQRGACGQGQED - PNSLRHK RW-SHAVCGTDGHTYANVCALQAASRRALQLSGTPVRQLQKGACPLGLHQ - LSSPRYK AEGAEDAVVCGSDGRTYPSLCALRKENRAARQRGALPAVPVQKGACEEAGTTRAGRLRRK

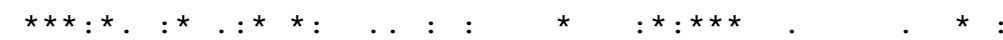

YNFIADVVEKIAPAVVHIELFRKNVFN-REVAVASGSGFVVSEDGLIVTNAHVVANYNF IADVVEKIAPAVVHIELYRKLPFSKREVPVASGSGF IVSEDGLIVTNAHVVTNFNF IADVVEKIAPAVVHIELFLRHPLFGRNVPLSSGSGF IMSEAGLI I TNAHVVSSNSAA YNF IAAVVEKVAPSVVHLQLFRRSPLTNQEIPSSSGSGF IVSEDGLIVTNAHVLTN-

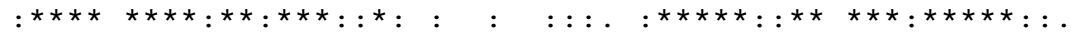

-KNRVKVELKNGASYDAKI KDVDEKADIALIKIDLPNKLPVLLLGRSADLRPGEFVVAI -KNRVKVELKNGATYEAKIKDVDEKADIALIKIDHQGKLPVLLLGRSSELRPGEFVVAI PGRQQLKVQLQNGDSYEATIKDIDKKSDIATIKIHPKKKLPVLLLGHSADLRPGEFVVAI -QQKIQVELQSGARYEATVKDIDHKLDLALIKIEPDTELPVLLLGRSSDLRAGEFVVAL

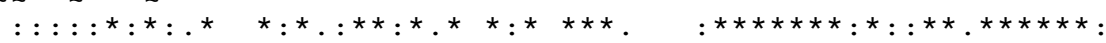

GSPFSLQNTVTTGIVSTTQRGGKELGLRNSDMDYIQTDAI INYGNSGGPLVNLDGEVIGI GSPFSLQNTVTTGIVSTTQRGGKELGLRNSDMDYIQTDAI INYGNSGGPLVNLDGEVIGI GSPFALQNTVTTGIVSTAQREGRELGLRDSDMDYIQTDAI INYGNSGGPLVNLDGEVIGI GSPFSLQNTVTAGIVSTTQRGGRELGLKNSDIDYIQTDAI INHGNSGGPLVNLDGDVIGI

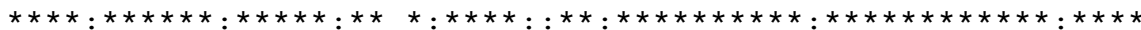

NTLKVTAGISFAI PSDKIRQFLAESYDRLARGRGTTKKRYIGVRMMTLTPSLSKELKGRL NTLKVTAGISFAI PSDKI KKFLTESHDRQAKGKAVTKKKYIGIRMMSLTSSKAKELKDRH NTLKVTAGISFAI PSDRITRFLTEFQDKQI KD-WKKRF IGIRMRTITPSLVDELKASN NTLKVTAGISFAI PSDRIRQFLEDYHERQLKGKAPLQKKYLGLRMLPLTLNLLQEMKRQD

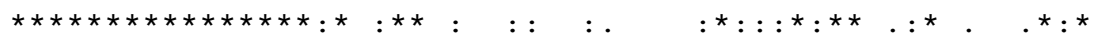
RDFPDITSGAYVIEVISKTPAAAGGLKEHDVI IS INGQR I STATDVSAI I KKESSLRVVV RDFPDVLSGAYI IEVI PDTPAEAGGLKENDVI IS INGQSVVTANDVSDVI KKENTLNMVV PDFPEVSSGIYVQEVAPNSPSQRGGIQDGDI IVKVNGRPLVDSSELQEAVLTESPLLLEV PEFPDVSSGVFVYEVIQGSAAASSGLRDHDVIVSINGQPVTTTTDVIEAVKDNDFLSIIV

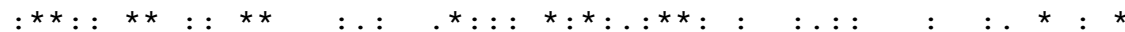

RRGNEDIILSIIPMEIDP RRGNEDIVITVIPEEIDP RRGNDDLLFS IAPEVVMLRGSQTLFLTVTPEIIN$* *::::: * *:$

Figure 3. Amino acid sequences alignment of zHtrA. mHtrA1, hHtrA3 and hHtrA4 
The HtrA1 proteins are homologous with the HtrA from bacteria. These HtrA proteins belong to a family of serine proteases that possess the aa sequence motif of GNSGGAL (in bacteria) or GNSGGPL (in mammals) in their active sites. In addition, they display a motif of TNAHV residues in the vicinity of GNSGGPL and the triad of histidine, aspartic acid and serine for their catalytic activity (Zumburn and Trueb, 1996; Hu et al., 1998). All of these motifs are present in protein (Figure 2,3). The serine protease active site sequence GNSGGPL is at aa $321 \pm 328$, the TNAHV residues are at aa $213 \pm 216$, and the catalytic triad histidine, aspartic acid and serine are at aa 216, 246 and 3245 respectively. This confirmed that the zebrafish HtrA represents an additional member of the HtrA serine protease family as Zebrafish HtrA1. Clausen et al. (2002) noted that one member of HtrA gene family is predicted in zebrafish, HtrA2, because lack of signal peptide. Here we reported that zebrafish also has a member of HtrA family which has signal peptide, i.e. zHtrA1.

\section{Expression of zHtrA1}

To observe the expression of zHtrA1, the RT-PCR and whole mount in situ hybridization was done. ZHtrA1 is not expressed at early stage of embryo as result from in situ that no signal was detected in 8 cells, $50 \%$ epiboly, $90 \%$ epiboly, $14 \mathrm{hpf}$ and $25 \mathrm{hpf}$ which also supported by RT-PCR result that at $30 \mathrm{hpf}$ did not amplify DNA fragment (Figure 4, 5) The HtrA1 seems to be expressed at least at $60 \mathrm{hpf}$, as indicated by positive result from RT-PCR and appearance of signal on in situ hybridization at this stage. Whole mount in situ hybridization showed that Zeb-HtrA1 was detected clearly only in the vertebral rudiments in the tail region (Figure 5).

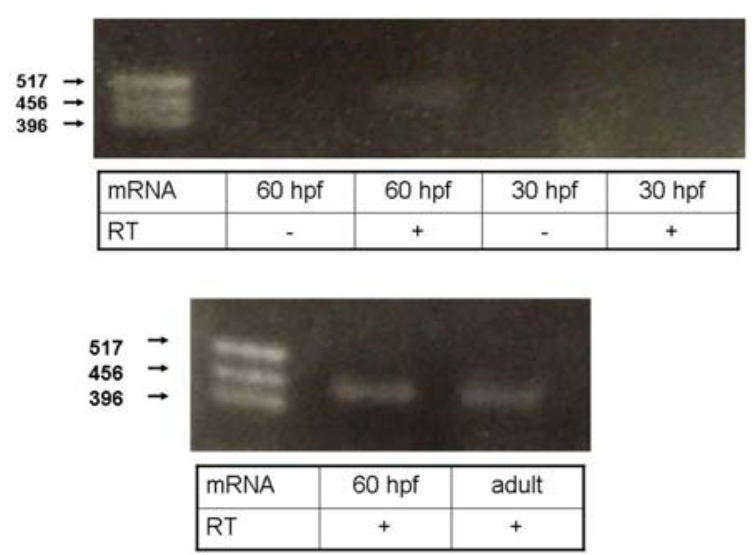

Figure 4. RT-PCR for zebrafish HtrA1. The various stages of zebrafish RNA in the present or absent of reverste transcriptase (RT) were used in the RT-PCR analysis. DNA marker size was indicated

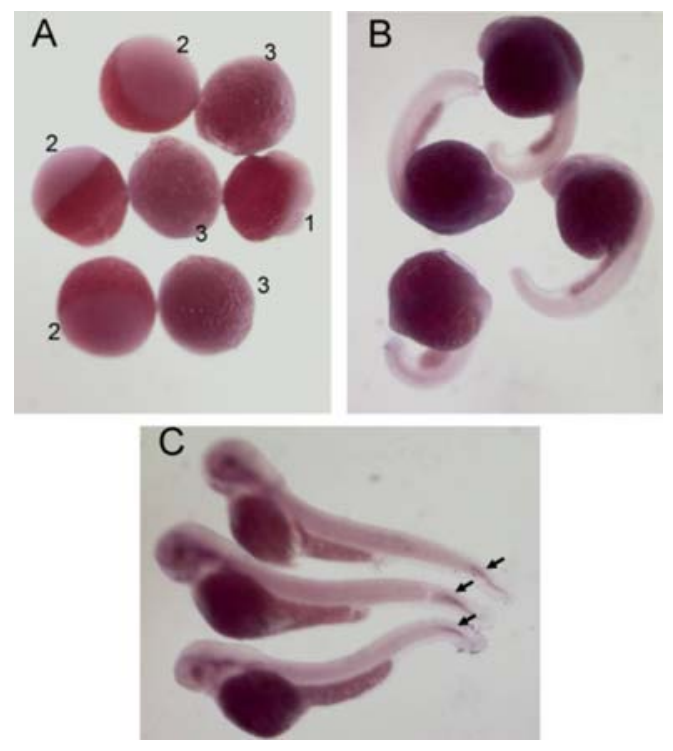

Figure 5. Whole mount in situ hybridization of zebrafish. The 16 cells (A1), shield (A2), 90\% epiboly egg stages, $30 \mathrm{hpf}(\mathrm{B})$ and $60 \mathrm{hpf}$ fry stages were analyzed for in situ hybridization using zHtrA1 probe. The zHtrA1 was expressed on the tail region of 60 hpf fry (arrow)

\section{Discussion}

\section{Organization of HtrA}

HtrA is a highly conserved family of serine proteases found in a wide range of 
species including microbes, plants, and animals. The number of those gene's members were varies among spesies. The number seems not correlated with the complexity of organisms. Since Clausen et al. (2002) notes that unicellular organism, $E$. coli at least has 3 members; the mammalian has at least 4 members. The fruit fly, D. melanogaster and $S$ pombe which their complexity higher than bacteria and lower than mammalian, only have one HtrA1 member. Our screening from $D$. melanophila cDNA library supported that only one gene found in this animal (data not shown).

Since the HtrA is distribute wide range of organisms, thus this gene is predicted exist in zebrafish. In this study we identified zebrafish HtrA member gene, zHtrA1. However this gene is different with the predicted by Clausen et al. (2002) which belong to HtrA2 member due to the lack of signal sequence in $\mathrm{N}$-terminal. It still does not know about the actual number(s) of HtrA gene in zebrafish. To address this question, the extensive screening should be carried out.

\section{HtrA expression}

HtrA1 has similar structure with HtrA3, HtrA4. Structure of N-terminal regions of mammalian HtrA1 and 3 are contain secretory signals at the $\mathrm{N}$-terminus followed by two domains; one similar to the insulinlike growth factor (IGF) binding protein domain and the other to the Kazal-type serine protease inhibitor domain (Clausen et al. 2002). Although this N-terminal part did not show cross immunoreaction between HtrA1 and HtrA3 (data not shown), those two genes seem have similarity in expression. HtrA1-3 are firstly expressed in later stage of embryo. The mHtrA1 and mHtrA3 were firstly expressed at $10.5 \mathrm{dpc}$ (Oka et al 2004) and at $9.5 \mathrm{dpc}$ (Tocharus et al., 2004) respectively. The zHtrA1 seems to be expressed at least at $60 \mathrm{hpf}$, as indicated by positive result from RT-PCR and appearance of signal on in situ hybridization at this stage (Figure 4, 5).

The HtrA1-3 seem to be expressed in the tissues closely associated with skeletal system, as showed in mouse HtrA1 (Oka et al., 2004), mouse HtrA3 (Tocharus et al. 2004). Our result support that note in different animal as zHtrA1 was detected clearly only in the vertebral rudiments in the tail region as judged by whole mount in situ hybridization (Figure 5). The expression in the skeletal system is closely related with TGF- $\beta$ expression (Oka et al., 2004), then the HtrA1 and HtrA3 have been provided their function as inhibitor signaling TGF- $\beta$ family protein (Oka et al., 2004; Tocharus et al., 2004). However, in zebrafish the HtrA1 and TGF- $\beta$ are firstly expressed at is different in stage. The TGF- $\beta$ family member in zebrafish have function in posterior and ventral development and are firstly expressed at embryonic shield or gastrulation (Hwang et al., 1997; Lele et al., 2001; Dickmeis et al., 2001). On the other hand zHtra1 is firstly expressed at $60 \mathrm{hpf}$ (Figure 4,5). The late expression of HtrA compare the BMP seems also occurred in the mouse. At first the both HtrA3 and -1 were not expressed in the core of the cartilaginous condensations. Interestingly, however, when the blood vessels invaded into the condensations and ossification started in the peri- and postnatal periods, the expression of HtrA3 and -1 were tremendously upregulated. Chondrocytes probably undergoing degeneration in the ossification center produced HtrA1 and -3 (Oka et al., 2004; Tocharus et al., 2004).

\section{Acknowledgement}

We thank to Dr. Kunio Yasuda and staff in Laboratory of Molecular and Development Biology NAIST for material and technical assistant in zebrafish. We are 
grateful to Mrs Sachiko Iida, Choryo Syuzo Company for constant encouragement and support through Iida Foundation. This paper is a part of dissertation by Murwantoko in Department of Molecular Biology, Nara Institute of Science and Technology, Japan.

\section{References}

Baldi, A., De Luca, A., Morini, M., Battista, T., Felsani, A., Baldi, F., Catricala C., Amantea, A., Noonan, D.M., Albini, A., Natali, P.G., Daniela, L., and Paggi, M.G., 2002, The HtrA1 serine protease is down-regulated during human melanoma progression and repress growth of metastatic melanoma cells. Oncogene, 21, 66846688.

Clausen,T., Southan, C., and Ehrmann ,M., 2002, The HtrA family of proteases: Implications for protein composition and cell fate. Mol. Cell., 10, 443-455.

Chien, J., Staub, J., Hu, S., EricksonJohnson, M.R., Couch, F.J., Smith, D.I., Crowl, R.M., Kaufmann, S.H., and Shridhar, V., 2004. A candidate tumor suppressor HtrA1 is downregulated in ovarian cancer. Oncogene, 23 (8), 1636-44.

Dikmeis, T., Rastegar, S., Aanstad, P., Clark, M., Fischer, N., Korzh, V., and Strahle, U., 2001. Expression of the anti-dorsalizing morphogenetic protein gene in zebrafish embryo. Dev. Genes Evol., 11, 568-571.

Faccio, L., Fusco, C., Viel, A., and Zervos, A.S. 2000. Tissue-specific splicing of Omi tress-regulated endoprotease leads to an inactive protease with a modified PDZ motif. Genomic, 68, 343-347.

Gray, C.W., Ward, R.V., Karran, E., Turconi, S., Rowles, A., Viglienghi, D., Southan, C., Barton, A., Fantom, K.G., West, A., Savopoulos, J.,
Hassan, N.J., Clinkenbeard, H., Hanning, C., Amegadzie, B., Davis, J.B., Dingwall, C., Livi, G.P., and Creasy, C.L., 2000. Characterization of human HtrA2, a novel serine protease involved in the mammalian cellular stress response. Eur. J. Biochem., 267, 5699-710.

$\mathrm{Hu}$, S., Carozza M., Klein M., Nantermet P., Luk, D., and Crowl, R.M., 1998. Human Htr A, an evolutionarily conserved serine protease identified as differentially expressed gene product in osteoarthritic cartilage. $J$. Biol. Chem., 273, 34406-34412.

Hwang, S.P., Tsou M.F., Lin, Y.C. and Liu, C.H., 1997. The zebrafish BMP4 gene: sequence analysis and expression pattern during embryonic development. DNA Cell. Biol., 16, 1003-1011.

Lele, Z., Nowak, M. and Hammerschmidt, M., 2001. Zebrafish admp is required to restrict the size of the organizer and to promote posterior and ventral development. Dev. Dyn., 222, 681687.

Ly, D.H., Lockhart, D.J., Lerner, R.A., and Schultz, P.G., 2000. Mitotic misregulation and human aging. Science, 287, 2486-24923.

Murwantoko, Yano,M., Ueta, Y., Murasaki, A., Kanda, H., Oka, C., and Kawaichi, M., 2004. Binding of proteins to the PDZ domain regulates proteolytic activity of HtrA1 serine protease. Biochem. J., 381, 895-904.

Nie, G., Li, Y., Minoura, H., Batten, L., Ooi, G.T., Findlay, J.K., and Salamonsen, L.A., 2003. A novel serine protease of the mammalian HtrA family is upregulated in mouse uterus coinciding with placentation. Mol. Hum. Reproduction, 9, 279-290. 
Oka, C., Tujimoto, R., Kajikawa, M., Kashiba-Takeuchi, K., Ina, J., Yano, M., Tsuciya, A., Ueta, Y., Soma, A., Kanda, H., Matsumoto, M., and Kawaichi, M., 2004. HtrA1 serine protease inhibits signaling mediated by TGF- $\beta$ family proteins. Development. 131 (5), 1041-53.

Pallen, M. and Wren, B., 1997. The HtrA family of serine proteases. Mol. Microbiol., 26, 209-221.

Shridhar, V., Sen, A., Chien, J., Staub, J., Avula, R., Kovats, S., Lee, J., Lillie, J., and Smith, D.I., 2002. Identification of underexpressed genes in early- and late-stage primary ovarian tumors by suppression subtraction hybridization. Cancer Res., 62, 262270.
Thompson, J.D., Higgins, D.G., and Gibson, T.J., 1994. CLUSTALW: Improving the sensitivity of progressive multiple sequence alignment though sequence weighting, position specific gap penalties and weight matrix choice. Nucleic Acids Res., 22, 4673-4680.

Tocharus, J., Tsuchiya, A., Kajikawa, M., Ueta, M., Oka, C., and Kawaichi, M., 2004. Developmentally regulated expression of mouse HtrA3 and its role as an inhibitor of TGF- $\beta$ signaling. Dev. Growth Differ., 46 (3), 257-74.

Zumbrun, J. and Trueb, B., 1996. Primary structure of putative serine protease specific for IGF-binding. FEBS Letter, 398,187-192. 